Eur. J. Clin. Chem. Clin. Biochem.

Vol. 31, 1993, pp. 239-244

(C) 1993 Walter de Gruyter \& Co.

Berlin - New York

\title{
Comparison of Direct Versus Indirect Determination of Zinc Concentration in Erythrocytes in Euthyroid and Hyperthyroid Subjects
}

\author{
By Beate Tiran ${ }^{1}$, O. Lorenz ${ }^{1}, A$. Tiran ${ }^{2}, W$. Buchinger $^{3}$ and $O$. Eber $^{3}$ \\ 1 Institut für Medizinische Biochemie, Karl-Franzens Universität Graz, Austria \\ ${ }^{2}$ Medizinische Universitätsklinik, Karl-Franzens Universität Graz, Austria \\ ${ }^{2}$ Krankenhaus der Barmherzigen Brüder Graz-Eggenberg, Austria
}

(Received August 31, 1992/January 12, 1993)

Summary: Zinc concentration in erythrocytes is a suitable marker of peripheral tissue response to thyroid hormones. Therefore, the determination of erythrocyte zinc concentration has become an important marker for duration of preexisting hyperthyroidism in the clinical laboratory. We compared a new indirect erythrocyte zinc determination method with a commonly used direct method in 42 euthyroid and 14 hyperthyroid subjects. Zinc concentrations (median and range) obtained by direct and indirect methods were 172.8 (134.4-241.1) and $176.8(143-243.9) \mu \mathrm{mol} / \mathrm{l}$ erythrocytes in the euthyroid group and $117.1(71-141.9)$ and $118.5(73-137)$ $\mu \mathrm{mol} / \mathrm{l}$ erythrocytes in the hyperthyroid group. Values measured by the indirect method were slightly higher in both groups. Regression analysis showed a good correlation $(r=0.967, p=0.0001)$. The influence of the anticoagulants, potassium EDTA and heparin, on erythrocyte and plasma zinc values was studied, and zinc concentrations in serum and plasma were compared. No statistically significant differences were found. Thus, the indirect determination of erythrocyte zinc concentration is a simple and rapid technique well suited for use in clinical laboratory work, yielding accurate and reliable results. For the indirect method reference concentrations were established in a collective of 102 thyroid healthy subjects. An erythrocyte zinc concentration of $176.3 \pm 23.9 \mu \mathrm{mol} / \mathrm{l}$ (mean $\pm \mathrm{SD}$ ) was found with a cut-off limit of $138 \mu \mathrm{mol} / \mathrm{l}$ to hyperthyroidism.

\section{Introduction}

The interaction between thyroid function and zinc metabolism has long been a matter of investigation $(1-3)$. It is a well known fact that during hyperthyroidism the zinc concentration in erythrocytes decreases and serum zinc is increased $(4,5)$. The reason for the decreased erythrocyte zinc concentration is inhibition of the synthesis of carbonic anhydrase-I isoenzyme in erythrocytes by high thyroid hormone concentrations. The greatest amount of zinc in erythrocytes is bound as a structural part of this enzyme $(6-8)$. Changes in erythrocyte zinc concentration, as a result of changes in thyroid function, take time to develop because of the relatively long half-life of erythrocytes. Therefore, erythrocyte zinc concentration reflects the patient's mean thyroid hormone con- centration over the previous several weeks and months $(9,10)$. For this reason it is possible to differentiate short from the long duration hyperthyroidism by determination of the erythrocyte zinc concentration. Lao et al. (11) reported that determination of erythrocyte zinc concentration makes it possible to discriminate between preexisting hyperthyroidism and transient hyperthyroidism in pregnancy due to hyperemesis gravidarum, and so facilitates the choice of therapy.

Erythrocyte zinc concentration is commonly measured directly: erythrocytes are separated from whole blood and the resulting pellet is analysed $(10,12)$. The separation and washing procedures have to be performed immediately after venous puncture, and they are labour intensive and time consuming. Indirect 
determination of erythrocyte zinc concentration by measuring serum and whole blood zinc and calculating the concentration in erythrocytes according to haematocrit values would be a suitable method for routine laboratories.

The aim of this study was to check the comparability of a direct and an indirect method for determining erythrocyte zinc concentration in euthyroid as well as hyperthyroid subjects, and to establish reference ranges for thyroid healthy subjects. The influence of several anticoagulants on erythrocyte and plasma zinc concentration was studied.

\section{Materials and Methods}

Reagents

Zinc standards were prepared from a $1 \mathrm{~g} / \mathrm{l}$ zinc chloride reference solution:(Merck No 9953). Triton X 100 was purchased from Serva, Chelex ${ }^{\circledR}$ resin from Bio Rad, zinc reference material from Nycomed (whole blood; Lot. No. 906, target value 70.5 $\mu \mathrm{mol} / \mathrm{l}$ ) and Merck (Qualitrol $\mathrm{N}^{\circledR}$ serum; Lot. No. 390, target value $17.7 \pm 1.2 \mu \mathrm{mol} / \mathrm{l})$.

All reagents were of analytical grade. All solutions were made with double distilled water.

\section{Apparatus}

All analyses for zinc were performed by flame atomic absorption spectrophotometry (Perkin Elmer 2380) with a zinc hollow cathode lamp (213.9 $\mathrm{nm})$, an air acetylene flame and instrumental conditions as described previously (13). Haematocrit, haemoglobin $(\mathrm{Hb})$ and erythrocyte count were determined on a Sysmex E 5000 analyser.

\section{Standards}

Working standard solutions were prepared from the stock solution mentioned above by diluting with double distilled water to zinc concentrations of 15.3 and $30.6 \mu \mathrm{mol} / \mathrm{l}$. To solve matrix problems for serum zinc determination, zinc standards were prepared in zinc-free human serum matrix. We improved the previously published zinc depletion $(13,14)$ by using Chelex ion exchanger instead of Dowex ${ }^{\oplus}$. Chelex ${ }^{\oplus}$ resin can be used directly, whereas Dowex resin had to be washed several times to remove excess acid. Chelex ${ }^{\circledast}$ resin $(4.5 \mathrm{~g})$ was weighed into polypropylene tubes, then $6 \mathrm{ml}$ of pooled human serum were added to each tube and slowly mixed with a rotating mixer for 16 hours. The tubes containing serum and resin were stored at $+4^{\circ} \mathrm{C}$; they are stable for several months.

Zinc-free serum matrix and standard working solutions (15.3 and $30.6 \mu \mathrm{mol} / \mathrm{l}$ ) were mixed $1: 2$ and diluted further with 3 aliquots of Triton X $100(1 \mathrm{~g} / \mathrm{l})$. The blank was prepared by diluting zinc-free serum matrix with Triton X $100(1 \mathrm{~g} / 1),(1: 5)$.

\section{Patient samples}

Forty two euthyroid and 14 hyperthyroid subjects were included in the study protocol. Thyroid function was checked by $\mathrm{fT}_{4}$, $\mathrm{fT}_{3}$ and thyrotropin. The euthyroid subjects had been hospitalised for health checks. Hyperthyroid patients had immunehyperthyroidism $(n=8)$ or thyroid autonomy $(n=6)$. Fasting blood samples were obtained in the morning and collected in polypropylene syringes with and without potassium EDTA. Syringes had been previously checked for trace metal contamination.
Blood in syringes without additives was centrifuged after clotting, and serum was transferred into new zinc-free polypropylene tubes and analysed for zinc concentration no later than the next day. Blood in syringes anticoagulated with potassium EDTA was used for measuring haematocrit, $\mathrm{Hb}$, erythrocyte count, zinc concentration in whole blood and in the erythrocyte pellet.

\section{Determination of zinc concentration}

\section{Direct method}

Erythrocytes were separated from plasma no later than four hours after venous puncture, as described elsewhere (3). Briefly, after centrifugation of $100 \mu$ l EDTA blood, the buffy coat was removed and the sediment erythrocytes were washed three times with $\mathrm{NaCl}(154 \mathrm{mmol} / \mathrm{l})$, then supplemented with Triton $\mathrm{X} 100$ $(1 \mathrm{~g} / \mathrm{l})$ to $100 \mu \mathrm{l}$ and haemolysed in $1200 \mu \mathrm{l}$ Triton X $100(1 \mathrm{~g} / \mathrm{l})$ (final total dilution 13-fold). Zinc concentration was expressed in micromol per litre erythrocytes.

\section{Indirect method}

Whole blood in twentyfive-fold dilution and serum in five-fold dilution with Triton $\mathrm{X} 100(1 \mathrm{~g} / \mathrm{l})$ were subjected to analysis. Values were calculated with the formula:

$$
\begin{aligned}
& \mathrm{Zn} \text { (erythrocytes) }[\mu \mathrm{mol} / \mathrm{l}] \\
& =\frac{\mathrm{Zn} \text { (whole blood) }[\mu \mathrm{mol} / \mathrm{l}]}{\text { Haematocrit }} \\
& -\frac{\mathrm{Zn} \text { (serum) }[\mu \mathrm{mol} / 1](1.00-\text { haematocrit) }}{\text { Haematocrit }}
\end{aligned}
$$

Additionally, fasting blood samples were obtained from 10 persons and collected in polypropylene syringes anticoagulated with potassium EDTA, or with heparin, and in syringes without additives. We tested the influence of different anticoagulants on erythrocyte zinc concentration and compared zinc concentrations in serum, heparinized plasma and EDTA plasma. Serum and plasma were separated from cellular blood components one hour after collection.

\section{Reference values}

Reference values were established on 102 thyroid healthy subjects (43 men, 59 women) with a mean age of $56 \pm 14$ years. Normal thyroid function was verified by normal function tests $\left(\mathrm{fT}_{3}, \mathrm{fT}_{4}\right.$, basal thyrotropin) and physical examination.

\section{Statistical analysis}

For statistical comparisons the non-parametric Wilcoxon signed ranks test was used. Correlation between the two methods was calculated by linear regression analysis. For normally distributed data, the mean and standard deviation (SD) were recorded. For non-normally distributed data, the median and range were recorded.

\section{Results}

\section{Imprecision studies}

The intra-assay imprecisions for the direct and indirect determination of erythrocyte zinc and serum zinc concentration were obtained by analysing samples 
Tab. 1. Imprecision of direct and indirect method and serum zinc determination

\begin{tabular}{|c|c|c|c|c|}
\hline & Sample & $\begin{array}{l}\text { Mean } \\
(\mu \mathrm{mol} / 1)\end{array}$ & $\begin{array}{l}\text { SD } \\
(\mu \mathrm{mol} / 1)\end{array}$ & $\begin{array}{l}\text { CV } \\
(\%)\end{array}$ \\
\hline \multicolumn{5}{|c|}{ Intra-assay imprecision $(\mathbf{n}=10)$} \\
\hline $\begin{array}{l}\text { Indirect method } \\
\text { ( } \mu \mathrm{mol} / \mathrm{l} \text { erythrocytes) }\end{array}$ & $\begin{array}{l}\text { Blood (low) } \\
\text { Blood (high) }\end{array}$ & $\begin{array}{l}109.3 \\
218\end{array}$ & $\begin{array}{l}1.7 \\
3.9\end{array}$ & $\begin{array}{l}1.6 \\
1.8\end{array}$ \\
\hline $\begin{array}{l}\text { Direct method } \\
\text { ( } \mu \mathrm{mol} / 1 \text { erythrocytes) }\end{array}$ & $\begin{array}{l}\text { Blood (low) } \\
\text { Blood (high) }\end{array}$ & $\begin{array}{l}115.4 \\
247.5\end{array}$ & $\begin{array}{l}1.1 \\
5.7\end{array}$ & $\begin{array}{l}1 \\
2.3\end{array}$ \\
\hline $\begin{array}{l}\text { Serum } \\
\text { ( } \mu \mathrm{mol} / 1 \text { serum) }\end{array}$ & $\begin{array}{l}\text { Serum (low) } \\
\text { Serum (high) }\end{array}$ & $\begin{array}{l}12.7 \\
22.2\end{array}$ & $\begin{array}{l}0.2 \\
0.6\end{array}$ & $\begin{array}{l}1.6 \\
2.8\end{array}$ \\
\hline \multicolumn{5}{|c|}{ Inter-assay imprecision (day to day; $n=10$ ) } \\
\hline $\begin{array}{l}\text { Indirect method } \\
\text { ( } \mu \mathrm{mol} / 1 \text { erythrocates) }\end{array}$ & Blood & 186.6 & 9.6 & 5.2 \\
\hline $\begin{array}{l}\text { Direct method } \\
\text { ( } \mu \mathrm{mol} / 1 \text { erythrocytes) }\end{array}$ & Blood & 188.2 & 10.6 & 5.6 \\
\hline $\begin{array}{l}\text { Serum } \\
(\mu \mathrm{mol} / 1 \text { serum })\end{array}$ & Serum & 12.7 & 0.5 & 4.1 \\
\hline
\end{tabular}

from 6 different individuals in low and high concentration ranges in ten replicates. Coefficients of variation (CV) ranged from 1 to $2.8 \%$ (see tab. 1).

For the determination of day-to-day imprecision, 3 samples from different individuals were analyzed on 10 successive days. For the direct method, ten aliquots of whole blood were washed and the resulting pellets frozen at $-20^{\circ} \mathrm{C}$ until analysis. For the indirect determination, whole blood and serum were frozen (10 aliquots of each) at $-20^{\circ} \mathrm{C}$ until analysis. Variation coefficients ranged between 4.1 and $5.6 \%$ (tab. 1).

\section{Accuracy studies}

For quality control of the zinc determination only lyophilised reference material (whole blood and serum) is commercially available. This material is therefore only suitable for checking the indirect method. We analysed zinc concentrations in whole blood and serum reference material, obtaining mean values of $70.2 \mu \mathrm{mol} / 1$ erythrocytes and $17.7 \mu \mathrm{mol} / 1$ serum with CVs $<5 \%(n=10$ each), close to the target values mentioned in the methods section.

To investigate the analytical recovery of zinc we added zinc in two different amounts (50 and $100 \mu \mathrm{g}$ respectively) to samples from six different individuals with previously determined zinc contents (10 replicates, mean \pm SD, see tab. 2). Zinc was added to the erythrocyte pellet for the direct method and to whole blood and serum for the indirect method. Mean analytical recoveries of $99-101 \%$ with SDs $<2.3 \%$ were obtained (see tab. 2).

\section{Comparison of direct and indirect method}

To examine differences between the two methods we analysed the erythrocyte zinc concentrations of 42 euthyroid and 14 hyperthyroid individuals directly

Tab. 2. Mean analytical recovery $(n=10)$ for zinc added to whole blood samples, erythrocyte pellets and serum

\begin{tabular}{|c|c|c|c|c|c|}
\hline & \multicolumn{2}{|c|}{$\begin{array}{l}\text { Concentration* } \\
\text { before addition }\end{array}$} & \multirow{2}{*}{$\begin{array}{l}\text { Amount } \\
\text { added } \\
(\mu \mathrm{g})\end{array}$} & \multicolumn{2}{|c|}{$\begin{array}{l}\text { Recovery } \\
(\%)\end{array}$} \\
\hline & Mean & SD & & Mean & SD \\
\hline $\begin{array}{l}\text { Indirect method } \\
(\mu \mathrm{mol} / 1 \text { erythrocytes) }\end{array}$ & $\begin{array}{l}168.1 \\
173.3\end{array}$ & $\begin{array}{l}3.4 \\
3.5\end{array}$ & $\begin{array}{r}50 \\
100\end{array}$ & $\begin{array}{l}100.9 \\
100.6\end{array}$ & $\begin{array}{r}2.1 \\
1.1\end{array}$ \\
\hline $\begin{array}{l}\text { Direct method } \\
(\mu \mathrm{mol} / 1 \text { erythrocytes })\end{array}$ & $\begin{array}{l}194.8 \\
209.4\end{array}$ & $\begin{array}{l}3.9 \\
4.8\end{array}$ & $\begin{array}{r}50 \\
100\end{array}$ & $\begin{array}{l}100.2 \\
101.3\end{array}$ & $\begin{array}{l}0.6 \\
2.3\end{array}$ \\
\hline $\begin{array}{l}\text { Serum } \\
(\mu \mathrm{mol} / 1 \text { serum })\end{array}$ & $\begin{array}{l}12.7 \\
15.5\end{array}$ & $\begin{array}{l}0.2 \\
0.3\end{array}$ & $\begin{array}{r}50 \\
100\end{array}$ & $\begin{array}{l}99.2 \\
100\end{array}$ & $\begin{array}{l}1.6 \\
1.9\end{array}$ \\
\hline
\end{tabular}

* Mean and SD $(\mu \mathrm{mol} / \mathrm{l})$ for samples from six different individuals analysed in ten replicates 


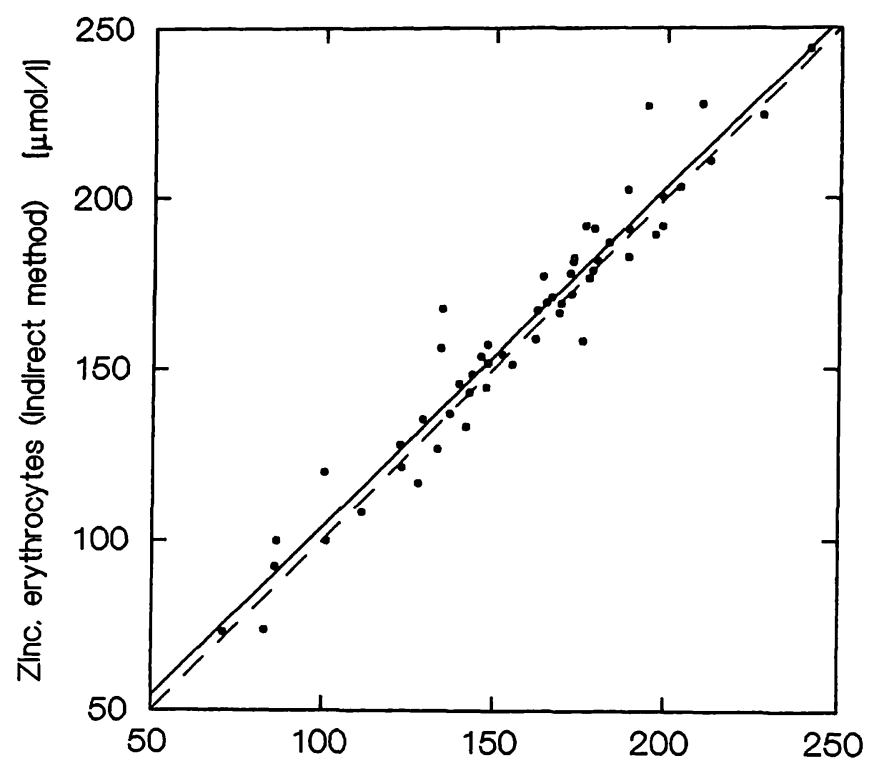

Zinc, erythrocytes (direct method) [ $\mu \mathrm{mol} / /]$

Fig. 1. Linear regression analysis of indirect versus direct erythrocyte zinc determination method in euthyroid and hyperthyroid subjects $(n=56) ; r=0.967, p=0.0001$, $y=0.992 x+305$.

- - line of identity.

and indirectly. Linear regression analysis showed a good correlation of the two methods ( $r=0.967$, $\mathrm{p}=0.0001, \mathrm{y}=0.992 \mathrm{x}+305$ ) (fig. 1). Zinc concentration median and range obtained by direct and indirect methods were 172.8 (134.4-241.1) and 176.8 $(143-243.9) \mu \mathrm{mol} / \mathrm{l}$ erythrocytes in euthyroid subjects and $117.1(71-141.9)$ and $118.5(73-137) \mu \mathrm{mol} / \mathrm{l}$ erythrocytes for hyperthyroid subjects (see fig. 2). The values measured by the indirect method were slightly higher in both groups. The differences of the medians were statistically significant in the euthyroid group $(p=0.005)$.

\section{Influence of potassium EDTA}

and heparinized blood on the direct zinc determination in erythrocytes

In 10 persons the zinc concentration in erythrocytes (mean \pm SD) was $162.6 \pm 11 \mu \mathrm{mol} / \mathrm{l}$ for EDTA blood and $164.8 \pm 14.1 \mu \mathrm{mol} / 1$ for heparinized blood. There was no statistically significant difference between the values of the two groups.

Comparison of the zinc concentration in serum, potassium EDTA plasma and heparinized plasma

To examine differences in the zinc concentrations of serum and plasma we determined the zinc concentrations in 10 persons. Zinc concentrations (mean \pm SD) were $11.3 \pm 2.8 \mu \mathrm{mol} / \mathrm{l}, 11.5 \pm 2.9 \mu \mathrm{mol} / \mathrm{l}$ and 11.5 $\pm 2.8 \mu \mathrm{mol} / 1$ in serum, EDTA plasma and heparin-

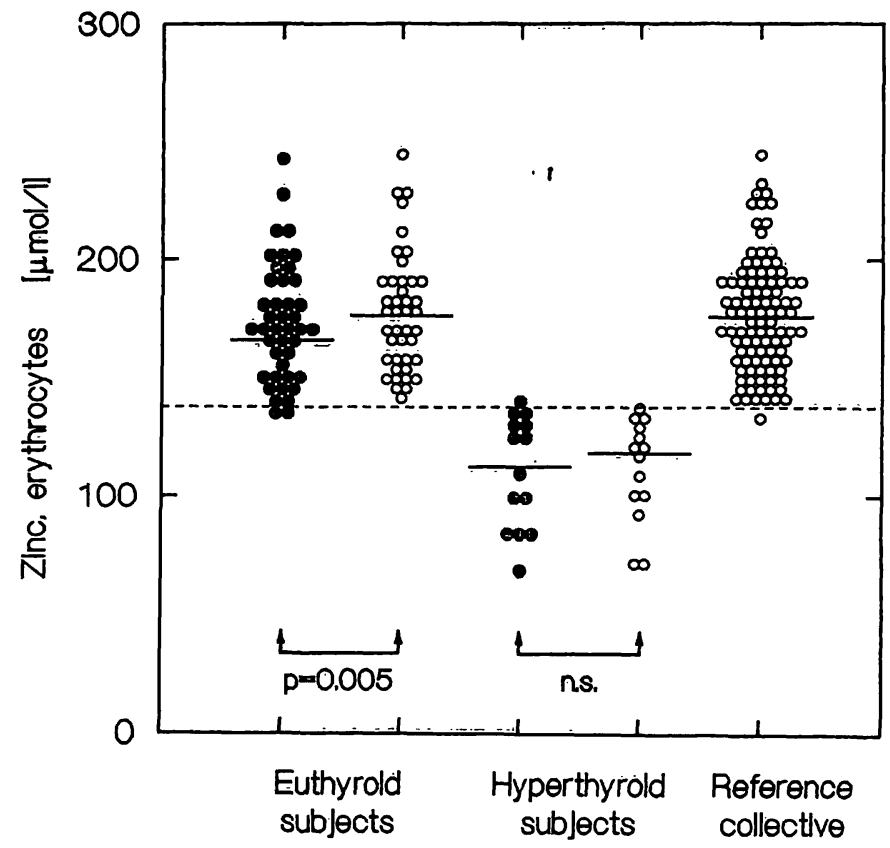

Fig. 2. Comparison of erythrocyte zinc concentration determined by direct and indirect method in euthyroid $(n=42)$ and hyperthyroid $(n=14)$ subjects and the reference collective of thyroid healthy individuals $(\mathrm{n}=102)$.

- direct method, 0 indirect method, median (euthyroid and hyperthyroid group) and mean (reference collective), -.- cut-off limit at $138 \mu \mathrm{mol} / \mathrm{l}$ erythrocytes.

ized plasma, respectively. There was no statistically significant difference between these values.

\section{Reference values}

Analysis of erythrocyte zinc concentrations in 102 subjects with normal thyroid function, using the indirect method, gave a concentration of $176.3 \pm 23.9$ $\mu \mathrm{mol} / \mathrm{l}$ erythrocytes (mean $\pm \mathrm{SD}$ ). In the same collective the serum zinc concentration was $12.2 \pm 2.6$ $\mu \mathrm{mol} / \mathrm{l}$ (mean $\pm \mathrm{SD}$ ). There was no significant difference between men and women. We recommend a cut-off limit of $138 \mu \mathrm{mol} / 1$ erythrocytes to hyperthyroidism (fig. 2).

\section{Discussion}

Zinc concentration in erythrocytes is a suitable marker of peripheral tissue response to thyroid hormones. The discrimination between short and long term hyperthyroidism is often important for the diagnosis of thyroid disease and therapy management. Therefore determination of zinc in erythrocytes has become important for the routine laboratory.

Direct determination of the erythrocyte zinc concentration is work intensive and time consuming. Separation and washing procedures have to be performed 
immediately after venous puncture. The washing procedure for one sample takes about 10 minutes and has to be performed very carefully to avoid any removal of erythrocytes. On the other hand, the indirect determination, as presented in this paper, can easily be performed in any clinical laboratory possessing flame atomic absorption spectrophotometry equipment. Measurement of one sample by flame atomic absorption spectrophotometry takes 30 seconds (double determination). Serum and whole blood are diluted differently before analysis, so that all sample results can be obtained from the same calibration curve. Although complicated sample handling can be avoided in the indirect method, it showed the same coefficients of variation as the direct method (average intraassay CV $1.7 \%$, day-to-day CV $5.2 \%$, see tab. 1). Quality control assurance is an important goal in a clinical laboratory. For quality control of zinc determinations only lyophilised reference material (whole blood and serum) is commercially available. Therefore only the indirect method can be checked, and not the direct one. Analytical recovery, tested by addition of 50 or $100 \mu \mathrm{g}$ zinc to six different clinical samples, averaged $100.7 \%$ for both the indirect and the direct method. However, when the two methods were compared by assaying 42 euthyroid and 14 hyperthyroid samples, the values measured by our indirect method were slightly higher than those measured by the direct one. In the euthyroid group this difference was $3.1 \%$ and was statistically significant ( $p=0.005$, see fig. 2 ), whereas in the hyperthyroid group the difference was not statistically significant. Data from the literature $(9-11)$ for a direct method agree with our data. In a method comparison study in the euthyroid concentration range, Deuster et al. (12) reported that their values from the indirect method were $2.5 \%$ higher than those found by the direct method. A possible explanation for this slight difference could be the binding of membrane-bound zinc by EDTA, which would be removed by subsequent washing steps. We therefore compared zinc concentrations in washed erythrocytes from EDTA and heparinized blood, but found no statistically significant difference between the two values. Therefore, it seems unlikely that considerable amounts of zinc are removed by EDTA. Another explanation for the slightly lower zinc concentration determined by the direct method could be the loss of erythrocytes by the washing procedure.

\section{References}

1. Swaminathan, R., Segall, N. H., Chapman, C. \& Morgan, D. B. (1976) Red blood cell composition in thyroid disease. Lancet $i, 1382-1385$.
In our comparison of zinc concentrations in serum, EDTA plasma and heparinized plasma we found no any statistically significant differences. In studies comparing heparinized plasma and serum, either no difference in zinc concentrations between serum and plasma were observed $(16,17)$ or a small difference was noted (15). In the latter study slightly higher serum values were attributed to the partial disintegration of platelets during serum clot retraction. Additionally, zinc concentration depends on the time between collection and separation of blood samples. Unseparated, there is an increase of $6 \%$ in the zinc concentration in serum and plasma in the first two hours after venous puncture (15). Therefore an early separation from cellular blood components is recommended.

To establish reference values for the presented indirect method, we measured the erythrocyte zinc content of 102 subjects with normal thyroid function, and obtained a mean value of $176.3 \mu \mathrm{mol} / 1$ with an approximately normal distribution of values. Assuming a cut-off erythrocyte zinc concentration of $138 \mu \mathrm{mol} / \mathrm{l}$, all but one of 102 samples had values over this limit. All 14 hyperthyroid subjects had values below this limit, and were therefore very well discriminated. It is important to know that changes in erythrocyte zinc concentration take time to develop. Patients with sudden onset of thyrotoxicosis due to destructive (subacute or silent) thyroiditis have normal erythrocyte zinc concentrations when they first arrive in the clinic (9). Therefore, determination of the erythrocyte zinc concentration gives additional information to that approved by thyroid function tests $\left(\mathrm{fT}_{3}, \mathrm{fT}_{4}\right.$, thyrotropin), about the duration, intensity and peripheral tissue response of hyperthyroidism. Further studies on the reliability of the proposed cut-off limit in connection with other peripheral tissue markers for thyroid hormones are in progress.

In conclusion, our paper shows that indirect determination of erythrocyte zinc concentration is an accurate, reproducible and reliable method. This simple and rapid technique is well suited for erythrocyte zinc determination in the clinical laboratory.

\section{Acknowledgement}

We are greatful to Christina Ruthofer for excellent technical assistance.

2. Nishi, Y., Kawate, R. \& Usui, T. (1980) Zinc metabolism in thyroid disease. Postgrad. Med. J. 56, 833-837. 
3. Aihara, K., Nishi, Y., Hatano, S., Kihara, M., Yoshimitsu, K., Takeichi, N., Ito, T., Ezaki, H. \& Usui, T. (1984) Zinc, copper, manganese and selenium metabolism in thyroid disease. Am. J. Clin. Nutr. 40, 26-35.

4. Buchinger, W., Leopold, B., Lind, P., Langsteger, W., Klima, G., Költringer, P., Wawschinek, O. \& Eber, O. (1988) Veränderung des Zinkspiegels im Serum, Vollblut und im Erythrozyten bei Schilddrüsenstoffwechselstörungen. Wien. Klin. Wochenschr. 18, 619-621.

5. Dolev, E., Deuster, P. A., Solomon, B., Trostmann, U. H., Wartofsky, L. \& Burman, K. D. (1988) Alterations in magnesium and zinc metabolism in thyroid disease. Metabolism 37, 61-67.

6. Taniguchi, N., Ishikawa, N. \& Kondo, T. (1978) Inhibitory effect of thyroxine on carbonic anhydrase $\mathrm{B}$ isoenzyme biosynthesis in rabbit reticulocyte lysates. Biochem. Biophys. Res. Commun. 85, 952-958.

7. Yoshida, K., Kiso, Y., Watanabe, T., Kaise, K., Kaise, N., Fukazawa, K., Mori, K., Abe, K. \& Yoshinaga, K. (1991) Clinical utility of red blood cell carbonic anhydrase I and zinc concentrations in patients with thyroid diseases. Metabolism 40, 1048-1051.

8. Gardiner, P. E., Gessner, H., Brätter, P., Stoeppler, M. \& Nürnberg, $H$. W. (1984) The distribution of zinc in human erythrocytes. J. Clin. Chem. Clin. Biochem. 22, 159-163.

9. Yoshida, K., Kiso, Y., Watanabe, T., Kaise, K., Kaise, N., Fukazawa, H., Yamamoto, M., Sakurada, T. \& Yoshinaga, K. (1990) Erythrocyte zinc concentration in patients with subacute thyroiditis. J. Clin. Endocrinol. Metab. 70, 788791.
10. Yoshida, K., Kiso, Y., Watanabe, T., Kaise, K., Kaise, N., Itagaki, Y., Yamamoto, M., Sakurada, T. \& Yoshinaga, K. (1990) Erythrocyte zinc in hyperthyroidism: Reflection of intergrated thyroid hormone levels over the previous few months. Metabolism 39, 182-186.

11. Lao, T. T. H., Chin, R. K. H., Swaminathan, R., Panesar, N. S. \& Cockram, C. S. (1987) Erythrocyte zinc in differential diagnosis of hyperthyroidism in pregnancy: A preliminary report. Brit. Med. J. 294, 1064-1065.

12. Deuster, P. A., Trostmann, U. H., Bernier, L. L. \& Dolev, E. (1987) Indirect vs direct measurement of magnesium and zinc in erythrocytes. Clin. Chem. 33, 529-532.

13. Wawschinek, O. (1984) Simple matrix modification procedure for determination of zinc in human serum by flame atomic absorption spectrophotometry. Atom. Spectr. 5, $32-33$.

14. Wawschinek, O. (1983) Eine Mikromethode zur Bestimmung von Zink im Serum mittels flammenloșer Atomabsorption. Mikrochim. Acta 3, 77-81.

15. English, J. L. \& Hambidge, K. M. (1988) Plasma and serum zinc concentration: Effect of time between collection and separation. Clin. Chim. Acta 175, 211-216.

16. Kosman, D. J. \& Henkin, R. I. (1979) Plasma and serum zinc concentrations. Lancet $1,1410$.

17. Kiilerich, S., Christensen, M. S., Naestoft, J. \& Christiansen, C. (1981) Serum and plasma zinc concentrations with special reference to standardized sampling procedure and protein status. Clin. Chim. Acta 114, 117-121.

Dr. Beate Tiran

Institut für Medizinische Biochemie

Karl-Franzens Univiversität

Harrachgasse 21/III

A-8010 Graz

Austria 